\title{
1. OBJECTIVES OF PASSIVE MARGIN DRILLING ${ }^{1}$
}

\author{
D.G. Roberts, Institute of Oceanographic Science, Wormley, Godalming GU8 5UB, Surrey, England \\ and \\ L. Montadert, Institut Français du Pétrole, Rueil Malmaison, France
}

Approximately two thirds of the world's surface is covered by the deep ocean basins. The margins of these basins are of significant geological and economic importance because they mark the boundary or transition between thin oceanic crust and the thick, chemically different continental or intermediate type of crust.

Although the ocean basin margins vary greatly in their bathymetric and geological expression, they can be divided into active and passive types on the basis of their seismicity. Passive margins, unless very young, lack earthquakes and widespread volcanism and typically comprise a continental shelf, continental slope, and continental rise sequence. Good examples are the margins of the North and South Atlantic oceans. Seismically active margins like those bordering the Pacific Ocean are, in contrast, associated with a trench, volcanism, mountain building, and earthquakes that extend down to as much as $700 \mathrm{~km}$ depth along a dipping zone. This subdivision is a fundamental one that is best understood in the framework of plate tectonics. Passive margins thus mark the initial site of rifting apart of a plate that is now the continent/ocean boundary within an accreting plate. In contrast, the active margins mark the boundary between two plates which are either converging with, or sliding past, each other with attendant deformation or destruction of crust.

The varying rates of accretion and destruction of plates have been deciphered using the Vine-Matthews hypothesis and the principles of plate tectonics. Reconstructions of the present continents show that about 200 m.y. ago all were joined into a single supercontinent Pangaea, the margins of which were almost all characterized by subduction. Since that time, Pangaea has been broken up by rifting that has largely shaped the margins of the present continents. One of the foremost problems of earth science is to understand the geological, climatological, and biological consequences of the conversion of a world with a single supercontinent and superocean into a world composed of several continents and several oceans.

Most knowledge of the evolution of the earth has been gleaned from the stratigraphic and paleontological record preserved in the sediments that thinly veneer the Earth's surface. Of the sediments younger than 200 m.y., about 65 per cent rest on thin oceanic crust of the deep ocean basins.

'This paper is for the Passive Margin Panel. The hypotheses and models of passive margin evolution were developed in discussions of the Passive Margin Panel over the period 1974-1977. Members of the Passive Margin Panel were: J. Curray (chairman), D.G. Roberts, A.W. Bally, L. Montadert, H. Kagami, K. Hinz, J. Grow, J. Ewing, R. Sheridan, H. Closs, H. Beiersdorf, J. Hunt, D.G. Moore, J. Thiede, E. Siebold, and D. Bernoulli.
About 60 per cent of these oceanic sediments are contained in a few vast wedges of sediment that underlie the continental margins and are mostly found along a few passive margins of either the rifted or sheared type.

The geological record contained within these sediments is the history of the birth of the oceans, their growth and the changing paleoenvironment of the oceans and the continents. However, data or models which would allow a deeper understanding of this history have been lacking. This is because most previous work by earth scientists concerned with the exploration of passive margins has been either reconnaissance in nature or concerned with specialized problems often of local interest. Until recently, the available knowledge, even of the most intensely studied margins was surprisingly small. In most cases, the data were confined to a few shallow oil wells on the shelf, seismic refraction profiles, sparse high-quality reflection lines on the shelf, slope, and rise, and some deep-sea drilling data, all of which is used to correlate with presumed analogous ancient deposits now uplifted and exposed in mountain belts.

These observations have yielded at best a geometric picture of the margin that shows a thick body of sediments for which only little stratigraphic and other information is available. The deep stratigraphic data in these sediments necessary to build a kinematic framework of passive margin evolution can only be obtained by deep-sea drilling. However, many of the problems discussed below cannot be solved by deep-sea drilling alone. Use of regional and site-specific multichannel seismic surveys as well as other geophysical methods in conjunction with drilling results provides the basis for the fullest interpretation of the chronology and processes involved in the construction of passive continental margins.

These data and comparison with present-day analogs representative of earlier stages in margin evolution offer a perspective within which our understanding of the problems and of the evolution of passive margins can be reviewed in more detail. Conceptually, the evolution includes the following phases: (1) rifting, (2) onset of spreading separation of continental crust and the accretion of oceanic crust in the gap between the continental blocks, and (3) post-rift evolution - subsidence of the rifted margins and shaping by sedimentary and tectonic processes.

\section{RIFTING}

Evidence for the nature of the rifting process that constitutes the initial stages of margin development depends heavily on the East African Rift system because syn-rift sediments and the pre-rift section have rarely been penetrated in the ocean basins. The rifting is considered to be preceded by a period of regional uplift which may be 
contemporaneous and accompanied by extensive volcanism (e.g., Burke and Whiteman, 1972; Neugebauer, 1978). Erosion of the uplifted region may thin the crust, resulting in isostatic uplift while thermal metamorphism of the lower crust may cause an additional thinning of the continental crust. The rifting may follow a subparallel or trilete pattern as exemplified by the Viking Graben of the North Sea (Ziegler, 1975) or the north margin of Biscay (Montadert et al., this volume). During this stage, the basic structural framework of the margin is determined by the pattern of rifting and fracture zone development that may also show evidence of palimpsest control. Within the rift, basic and alkaline intrusive rocks may be intercalated with contemporaneous coarse clastic continental sediments. During this stage, the effect of uplift is to direct drainage away from the rift valley thus restricting clastic sediment supply. The altitude (subaerial or submarine) of the rift valley floor may profoundly influence syn-rift sedimentation. On one hand, as in the Afar depression, repeated transgressions may result in evaporite deposition on the extending continental crust whereas, on the other hand, such as the North Sea, a deep submarine environment may have been created by the end of rifting.

\section{ONSET OF SPREADING}

After rifting, oceanic crust begins to accrete at the edges of the separating continental blocks of lithosphere. The nature of the change from rifting to spreading, and thus the geology of the continent/ocean boundary formed at this time, is not fully understood. Overlaps and underlaps between reconjugated continents suggest variations in the width of the continent/ocean boundary zone that may reflect differing amounts of extension in the rifting stage and the variable geology of the boundary. In many areas, however, oceanic magnetic anomalies and a characteristic isostatic gravity anomaly suggest that the continent/ocean boundary may be a narrow zone, linear over hundreds of kilometers. Seismic refraction data and multichannel seismic reflection profiles across the boundary zone are sparse but suggest considerable variation. For example, multichannel profiles across the boundary show reflections below the oceanic "basement"' beneath the Walvis Ridge, Lofoten Basin, Vøring Plateau, and west of the Rockall Plateau. These may indicate sediments interbedded with lavas. In Biscay, however, a sharp change in basement character occurs at the continent/ocean boundary.

The change from rifting to accretion marks a major change in the thermal regime of the margin. During rifting, the heat source had remained fixed beneath the rift axis but, on spreading, moved away from the continent/ocean boundary allowing it to cool and thus subside. The subsidence has been considered to allow wider transgression of the margin often revealed as an important unconformity with onlap that separates the faulted syn-rift sediments from the unfaulted post-rift sediments. Another important effect of subsidence may be to gently tilt the margin oceanward, thus reversing the drainage pattern. During this early spreading stage, fracture zones and aseismic ridges may profoundly influence sedimentation. In the South Atlantic Ocean, for example, the restricted Lower Cretaceous paleoenvironment (evaporites, sapropels) may have been controlled by the Walvis Ridge and Rio Grande Rise.

\section{POST-RIFT EVOLUTION}

The subsequent evolution of the margin is a function of both age and the poorly understood interplay between subsidence, sedimentation, climate, and ocean circulation. Two types of margins appear to exist - starved and mature margins. Starved margins are characterized by a thin prograding sedimentary cover and may be chronologically old or young. Examples include the west margin of Rockall Plateau and the Bay of Biscay. Mature margins are characterized by a $10-\mathrm{km}$ prograding wedge of sediments and are exemplified by the east margin of North America.

The geological processes that control the nature of the sediments and the evolution of margins into these two types are poorly understood. One effect of subsidence and sediment loading is to deeply bury the first post-rift sediments as the margin progrades oceanward. Alternatively, reef growth on marginal basement highs may keep pace with subsidence resulting in the accumulation of thick sequences of shallow water carbonates that may in turn be buried.

The lithology and volume of sediments that comprise the post-rift sequence on both starved and mature margins clearly depends on the oceanic paleoenvironment climate, sea level, and the size and geology of the continental hinterland. The ocean basin margins distort the largely winddriven latitudinal surface water circulation to produce eastern and western boundary currents and major divergences. These boundary currents separate the stable central water masses and the highly variable coastal water masses over the margin. Changes in ocean basin circulation can therefore profoundly influence sediment dynamics along continental margins producing large hiatuses in the geological record. Fluctuations in the carbonate content of the sediments are apparently due to worldwide changes in the carbonate compensation depth during the Cenozoic and Mesozoic. These changes also seem to correlate with the sequence of global transgressions and regressions. The eustatic changes in sea level may also reflect changes in spreading rate which alter the cross-sectional area of mid-ocean ridges and hence ocean basin volume and circulation. There has also been speculation that the apparent correlation between spreading rate changes and hiatuses recorded on the margins, and regional warping of the margin may indicate that the continental part of a plate responds to spreading rate changes in a way not yet understood. Such changes apparently do not involve renewed faulting on the margin. The relationships between these factors are not yet known but clearly provide an important matrix for understanding both the geology on land and beneath the margins.

Although some of the significant problems of passive margin drilling have been briefly discussed above, it is difficult to distinguish these problems from regional and/or local problems. A key criterion in making this distinction is that problems identified in more than one region be considered a general problem. In the preparation of the passive margin drilling program, lists of geological and geophysical problems submitted by the earth science community were culled and collated into a number of general fundamental problems resolvable by drilling.

In the description of these problems and the objectives of passive margin drilling, it is difficult to avoid repetition because the evolution and genesis of structure is almost 
inseparably linked with the genesis and evolution of sedimentary sequences. The problems and objectives are listed as: (1) related to structural evolution, (2) the genesis and evolution of sedimentary sequences, and (3) geophysics.

\section{PROBLEMS RELATED TO STRUCTURAL EVOLUTION}

\section{Continent/Ocean Boundary}

A precise geological and geophysical description of the boundary between continental and oceanic crust is not yet available and the significance of variations in the nature of the boundary as a function of the change from rifting to spreading and the environment of rifting is obscure. It should be noted that the continent/ocean boundary along passive margins associated with transform faulting is suspected to differ. In both cases, later decoupling along the boundary has been invoked to explain faulting of the post-rift sequence.

\section{Attenuation of the Crust and/or Lithosphere}

The geophysical results reported from many margins show that they are underlain by an attenuated crust. Although attenuation during rifting has been favored, attenuation accompanying much of the subsidence of the margin has also been postulated. Differing mechanical models for the attenuation include: thermal expansion, uplift, and erosion; flow of the lower crust accompanied by subsidence; extension by rotational block faulting along listric normal faults; subcrustal erosion; ductile thinning; metamorphism of the lower crust during any of these processes. Critical information in distinguishing between these models and conceiving new models can only be achieved by drilling holes on either side of the continent/ ocean boundary. The hole on the continental side of the boundary would provide, by penetrating through syn- and pre-rift sediments, the timing of rifting and the change in elevation of the continent before and during rifting. For example, if the change from pre-rift to post-rift sediments is from a shallow marine to a deep-water environment, it implies that there may have been substantial subcrustal erosion. The results may be anticipated to bear on the validity of the widely used East African analog and on the nature of the oldest oceanic crust.

\section{Tectonic History and Styles of Deformation}

Many multichannel seismic reflection profiles show substantial block faulting beneath a relatively undisturbed sediment wedge. In some cases however, such block faults are absent and the structure is apparently a downward flexure. On other transform margins, transcurrent faulting is the dominant structural style. The cause of these differences in structural style is not well understood but may be related to the pre-existing structural fabric of the crust or lithosphere beneath the margin. The differences may also reflect the mechanism by which the crust was attenuated during rifting. The contrasting structural style may also bear on the contentious nature of the marginal ridges postulated to underlie continental margins. Such marginal ridges have also been considered to result from differential subsidence, reactivation, subsequent uplift, or carbonate build-up.
Massive subsidence evidenced by the occurrence of shallow water sediments at depth has taken place on many margins but the time and space relationship of subsidence in relation to rifting and attenuation has yet to be unraveled. Although a substantial amount of subsidence is due to sediment loading, the existence of starved margins, such as the Bay of Biscay, showing considerable subsidence suggests that loading is not the only contributing factor. Dating of continuously cored sections will yield accurate measurements of subsidence rates which may then be related to tectonic and eustatic cycles, as well as to regional warping of the continental hinterland.

\section{PROBLEMS RELATED TO THE GENESIS AND EVOLUTION OF SEDIMENTARY SEQUENCES}

The undisturbed sedimentary record of passive continental margins is a monitor of changes in ocean surface-water circulation, the vertical stratification and characteristics of the water column, the paleoenvironment of the continental hinterland and the juvenile rift.

\section{Continental Hinterland and Climate}

Continental margins act both as sinks and pathways for the dispersion of terrigenous material delivered as particles or in solution from the continental hinterland. The volume and lithological composition of this input is controlled by the geology of the continental hinterland, by the climatic processes above it, and by the size of the drainage basins which supply the terrigenous material. The climatic zonation of the earth also controls the amount and composition of organic material swept from the land into the sea. The nature and lithology of margin sediments thus provide a crucial link between the oceanic, epicontinental and continental paleoenvironments of great importance in understanding the geological record.

\section{Oldest Clastic and Volcanic Deposits}

The syn-rift sediments which filled the earliest rift have never been drilled or sampled in a major ocean. The nature of these sediments is fundamental to determining the altitude of the continent at the time of rifting. The quantitative importance of any associated volcanism (and thus the validity of East African analog) is significant in assessing the change in environment between rifting and spreading.

\section{Early and Later Restricted Marine Paleoenvironments}

Although the syn-rift sediments have rarely been sampled, the early post-rift sediments may record the early, often restricted paleoenvironment of the small ocean basin. For example, the narrow Mesozoic South Atlantic Ocean and the Cenozoic Red Sea represent typical oceanic depositional environments of halite. Carbonaceous sediments are also of frequent occurrence, often in association with salt deposits. However it is not clear if such deposits result from a euxinic bottom water mass or from the massive input of detrital carbon from the continental hinterland. It has also been suggested that anaerobic sediments with similar characteristics can be preserved under an oceanic midwater oxygen minimum. The distribution pattern of these Cretaceous carbonaceous sediments along passive margins is unknown, but in several regions it is clear that their depo- 
the accumulation of large volumes of platform carbonates on the adjacent shelf. The paleoenvironment and the relationship of these diverse facies remains to be understood.

\section{Oceanic Surface Water Circulation}

The distortion of the wind-driven latitudinal surface water circulation results in western and eastern boundary currents along the continental edge and in major divergences which can be assumed to represent the most unstable and sensitive components of the oceanic surface water circulation. The boundary currents separate the stable stratified central water masses of the ocean from the highly variable turbulent coastal water masses over the inner part of the continental margin. The establishment and history of this hydrographic regime can only be studied by drilling transects across passive continental margins. Due to the unusually rapid sedimentation rates, the high resolution of the sedimentary record provides the possibility of understanding the development of the pelagic environment.

\section{Carbonate Platforms}

The important carbonate platforms which have developed along passive margins are restricted to the relatively warm surface-water masses of the tropical-subtropical late Mesozoic and Cenozoic climatic belts. These platforms are of great interest as monitors of sea level and thus as a detailed record of the subsidence of passive margins.

\section{Oceanic Water Column}

Drill sites on continental margins also provide an insight into the vertical structure of the water column through time because the intermediate and deep ocean water masses impinge on the rise and slope. There is as yet little information on the temperature and circulation of deep bottom water in the pre-glacial Mesozoic and Cenozoic oceans. Such information may be provided by isotopic paleontology and the studies of magnetic anisotropy.

\section{Hiatuses and Sea-Level Fluctuations}

The good correlation of the late Mesozoic and Cenozoic calcite compensation depth with the sequence of eustatic sea-level fluctuations over the inner part of the continental margins demonstrates the intimate link between the oceanic and the continental paleoenvironment. Hiatuses in the stratigraphic record from passive continental margins mark oceanographic events which have resulted in non-deposition or erosion. These events seem to correlate with seismic indicators for transgression and regression. Their global synchroneity and occurrence has led to the hypothesis that they have been caused by eustatic sea-level fluctuations that reflect major changes in sea-floor spreading and/or other global tectonic events (besides the pulsations of the late Cenozoic glacial ice sheets).

\section{Continental Margin Sediment Cover Due to Late Cenozoic Glacial Events Versus Sections Not Influenced by Glaciation}

The abnormal glacial events which characterize most recent geological time have had great impact on the paleoclimate and paleoceanography of the Earth. Glacio-eustatic and isostatic sea-level fluctuations due to the expansion and retreat of the ice sheets have distorted the distribution of shallow and deep water sediment facies along margins. Glacial relict sediments remain abundant on the shelves some 20,000 years after the last glacial maximum, and it is clear that continental margins have not yet returned to their non-glacial equilibrium facies distribution. It is therefore important to compare and contrast pre-glacial and glacial sedimentary sequences.

\section{Diagenesis of Sediments}

The early diagenesis of marine sediments occurs in the top few meters of the ocean floor. Following this early diagenesis, lithification proceeds with the expulsion of interstitial waters, expulsion of water associated with the collapse of clay minerals, and reduction of porosity and permeability. This results in redistribution of fluids into porous and non-porous layers. Migration of the fluids leads to chemical reactions between the pore fluids and the host rocks. In this context, the thermal history of the sediments is of great importance. The diagenetic history of passive margin sediments is of extraordinary importance because they form a genetic analog to the thick sedimentary sequences preserved in epicontinental basins on land and exposed in fold belts. These studies can be best made using well logging and continuous coring.

\section{Organic Diagenesis}

The diagenesis of organic matter with depth is important in understanding the cycle of carbon between lithosphere, biosphere, and atmosphere and in processes such as the origin and maturation of petroleum. The source, maturation, preservation, and concentration of organic matter in the vast volume of sediments comprising the slope and rise is virtually unknown and, as such, represents a major gap in understanding the carbon cycle. Organic studies can also quantify geological events such as the total overburden removed during erosion, paleogeothermal gradients, and thermal alteration caused by igneous intrusion.

\section{GEOPHYSICS}

Many geophysical problems have been alluded to in this review. Other problems of importance include the cause of gravity edge anomalies, magnetic slope anomalies, the nature of the quiet magnetic zones, and the composition of the diapiric structures observed on seismic reflection profiles.

It must be stressed that geophysical techniques are the only means of acquiring subsurface information on a regional scale. Calibration of the interpreted geophysical data by drilling is a prerequisite in building regional, structural, and stratigraphic models of passive margins.

\section{REFERENCES}

Burke, K. and Whiteman, A.J., 1973. Uplift, rifting and the break-up of Africa. In Tarling, D.H. and Runcorn, S.K. (Eds.), Implications of continental drift for the earth sciences: New York (Academic Press), p. 735-756.

Neugebauer, H.J., 1978. Crustal doming and the mechanism of rifting, Tectonophysics, v. 45, p. 159-186.

Ziegler, W.H., 1975. Outline of the geological history of the North Sea. In Woodland, A.W. (Ed.), Petroleum and the continental shelf of northwest Europe: London (Applied Science Publishers), p. 165-190. 